\title{
Effectonderzoek naar de ouderinterventie Pittige Jaren
}

\author{
Joyce Weeland · Rabia R. Chhangur · Daniëlle van \\ der Giessen · Walter Matthys · Bram Orobio de Castro • \\ Geertjan Overbeek
}

\section{Samenvatting}

Deze studie onderzoekt of de preventieve variant van de ouderinterventie Pittige Jaren (in het Engels The Incredible Years; IY) effectief is in het verminderen van externaliserende gedragsproblemen en of veronderstelde moderatoren (d.w.z., ernst van probleemgedrag bij aanvang van de interventie, geslacht kind, sociaaleconomische status, gezinssamenstelling en het aantal interventiesessies waaraan ouders deelnamen) invloed hebben op deze effectiviteit.

Dit artikel is een vertaling van een eerder gepubliceerd Engelstalig artikel: Weeland, J., Chhangur, R.R., Giessen, D. van der, Matthys, W., Orobio de Castro, B., \& Overbeek, G. (2017). Intervention effectiveness of The Incredible Years: new insights into sociodemographic and intervention-based moderators. Behavior Therapy, 48(1), 1-18.

Joyce Weeland, Rabia Chhangur, en Walter Matthys zijn gecertificeerde The Incredible Years (IY) -groepsleiders. Joyce Weeland, Rabia Chhangur en Geertjan Overbeek zijn betrokken geweest bij de uitvoering van de interventie binnen de huidige studie. Geen van de auteurs heeft financieel belang bij de interventie of de resultaten van het huidige onderzoek.

J. Weeland en R.R. Chhangur hebben in gelijke mate bijgedragen aan het onderzoek en artikel. http://www.pittigejaren.nl/

http://www.nji.nl/nl/Databank/Databank-Effectieve-Jeugdinterventies/Erkende-interventies/ Incredible-Years-(Basis).html

http://www.orchids-studie.nl/

Dr. J. Weeland $(\varangle) \cdot$ Dr. D. van der Giessen · Prof. dr. G. Overbeek

afdeling Pedagogiek, Onderwijskunde en Lerarenopleiding, Universiteit van Amsterdam, Postbus 15776, 1001 NG Amsterdam, Nederland

e-mail: j.weeland@uva.nl

Dr. R.R. Chhangur

Gemeente Amsterdam, Amsterdam, Nederland

Prof. dr. W. Matthys

afdeling Orthopedagogiek: Psychosociale Problemen, Universiteit Utrecht, Utrecht, Nederland

Prof. dr. B. Orobio de Castro

afdeling Ontwikkelingspsychologie, Universiteit Utrecht, Utrecht, Nederland 
In een gerandomiseerd gecontroleerd onderzoek, bestaande uit een voormeting, nameting en follow-up, zijn er data verzameld (zowel via vragenlijsten als observaties) van 387 ouders en hun kinderen in de leeftijd van 4-8 jaar (Mleeftijd=6,21 jaar; $S D=1,33 ; 55,3 \%$ jongens).

IY leidde tot een toename van positief opvoedgedrag (zowel gerapporteerd als geobserveerd) en een afname van negatief opvoedgedrag en gedragsproblemen bij kinderen (gerapporteerd). We vonden echter geen systematisch bewijs dat de onderzochte moderatoren deze effecten beïnvloedden. Dit wijst erop dat de effecten van IY generaliseerbaar zijn naar een brede populatie in een preventieve setting.

\section{Trefwoorden}

gerandomiseerde gecontroleerde trial - The Incredible Years / Pittige Jaren • moderatoren

\section{Effectiveness of the parenting intervention 'The Incredible Years'}

\section{Abstract}

We tested the effectiveness of the parenting training 'The Incredible Years' (IY) in reducing child externalizing problem behaviour in a prevention setting, and the effects of previously suggested moderators (i.e. initial severity of the externalizing problem behaviour, child gender, socio-economic status, family composition and number of sessions that parents attended).

In a randomized controlled trial consisting of pre-test, post-test and follow-up measurements, data were collected (through both questionnaires and observations) on 387 parents and children aged 4 to $8\left(M_{\text {age }}=6.21\right.$ years; $S D=1.33$; $55.3 \%$ boys).

IY was effective in increasing positive parenting (reported and observed) and decreasing both negative parenting (reported) and child problem behaviour (reported). No systematic evidence emerged for the putative moderation of IY effectiveness. This indicates that the intervention effects of IY can be generalized to a broad population of families in a prevention setting.

\section{Keywords}

randomized controlled trial $\cdot$ The Incredible Years $\cdot$ moderators

\section{Inleiding}

\section{Ouderinterventies en moderatoren}

Opvoedgedrag van ouders hangt samen met het (negatieve en positieve) gedrag van hun kinderen (bijv. Karreman et al. 2006; Rothbaum en Weisz 1994; Zahn-Waxler et al. 1990). Eerder onderzoek toont aan dat ouderinterventies gericht op een afname van negatief opvoedgedrag (o.a. het niet consequent toepassen van straf- 
fen en belonen) en een toename van positief opvoedgedrag (o.a. effectief grenzen stellen) een effectieve methode zijn om externaliserende gedragsproblemen (hierna probleemgedrag genoemd) bij kinderen aan te pakken of zelfs te voorkomen (voor meta-analyses zie McCart et al. 2006; Menting et al. 2013; Sandler et al. 2011). Dit geldt ook specifiek voor de Nederlandse context (zie Leijten et al. 2016; Menting et al. 2015). Deze ouderinterventies beogen een positieve verandering in het opvoedgedrag van ouders teweeg te brengen en via de opvoeding uiteindelijk positieve veranderingen in het gedrag van het kind. Vroeg ingrijpen bij beginnende gedragsproblemen is belangrijk, omdat vroege gedragsproblemen verdere problemen in de levensloop van het kind voorspellen en negatieve gevolgen hebben voor het kind (bijv. psychopathologie), het gezin (bijv. opvoedstress) en de samenleving (bijv. sociale en economische kosten) (Jokela et al. 2009; Olson et al. 2017; Scott et al. 2001; Stumm et al. 2011).

Een van de meest gebruikte en onderzochte ouderinterventies in Nederland is de effectief bewezen 'Pittige Jaren' (The Incredible Years; IY): een groepstraining voor ouders van kinderen vanaf drie jaar die dwars en opstandig gedrag vertonen. De interventie is onder meer gebaseerd op Pattersons sociale leermodel, Bandura's self-efficacy-theorie en Bowlby's hechtingstheorie. Specifiek richt de interventie zich op het verminderen van dwars en opstandig gedrag door het verbeteren van de ouder-kindrelatie, ouders meer aandacht te laten schenken aan positief gedrag, ouders negatief gedrag op een duidelijke en positieve manier te laten begrenzen en ouders tevens zelf het goede voorbeeld te laten geven. De effectiviteit van IY is in Nederland meerdere malen onderzocht (Leijten et al. 2017; Menting et al. 2014; Posthumus et al. 2012) en heeft inmiddels het predicaat 'effectief volgens sterke aanwijzingen' gekregen van de erkenningscommissie effectieve jeugdinterventies van het NJI (https://www.nji.nl/nl/Databank/DatabankEffectieve-Jeugdinterventies/Erkende-interventies/Incredible-Years-(Basis).html).

De gemiddelde effectgrootte van ouderinterventies, waaronder IY, in een geïndiceerde preventieve setting (gericht op het voorkomen van verdere toename van beginnende gedragsproblemen tot een stoornis) is $d=0,20$. Dat is relatief klein vergeleken met de effectgrootte in een behandelingsetting $(d=0,50)$ (McCart et al. 2006; Menting et al. 2013; Reyno en McGrath 2006). Daarnaast laat onderzoek zien dat de effectiviteit van ouderinterventies beïnvloed wordt door sociaal-demografische (Gardner et al. 2010; Scott en O'Connor 2012) en interventie-specifieke moderatoren (Wilson en Lipsey 2001). Recente meta-analyses van studies naar de effectiviteit van ouderinterventies in het algemeen (Leijten et al. 2013; Lundahl et al. 2006) en specifiek naar de effectiviteit van de ouderinterventie IY (Menting et al. 2013) lieten zien dat in het bijzonder de ernst van probleemgedrag bij aanvang van de interventie, het geslacht van het kind, de sociaaleconomische status (SES), de gezinssamenstelling en het aantal interventiesessies waaraan ouders deelnamen, mogelijk belangrijke moderatoren zijn die de effectiviteit beïnvloeden. 


\section{Ernst van de problematiek bij aanvang van de interventie}

De ernst van de problematiek bij aanvang van de interventie kan van invloed zijn op de grootte van interventie-effecten (Leijten et al. 2013; Lundahl et al. 2006; Menting et al. 2013). Aan de ene kant blijkt dat de ernst van probleemgedrag bij aanvang van de interventie ruimte geeft voor meer verbetering en dus een sterker effect van de interventie (Gardner et al. 2010). De ernst van de gedragsproblemen zorgt daarnaast wellicht ook voor een verhoogde motivatie van ouders om zich in te zetten voor verandering tijdens de interventie. Aan de andere kant blijkt dat de ernst van probleemgedrag ook juist kan zorgen voor een kleiner effect van de interventie (Kazdin 1995; Ruma et al. 1996). Dit kan komen doordat er ook andere risicofactoren, samenhangend met ernstig probleemgedrag, spelen bij het kind (bijv. comorbiditeit van psychopathologie), bij de ouder (bijv. stress) en/of in de omgeving (bijv. lage SES), die een negatieve invloed kunnen hebben op de motivatie en de betrokkenheid van ouders om op een succesvolle manier een opvoedinterventie te volgen.

\section{Geslacht van het kind}

Ouderinterventies hebben vaak een sterker effect voor jongens dan voor meisjes (Gardner et al. 2010; maar zie review McMahon et al. (2008) voor tegenstrijdige resultaten). De invloed van het geslacht op de effectiviteit van een interventie kan gedeeltelijk verklaard worden door de samenhang met de ernst van probleemgedrag bij aanvang van de interventie (jongens vertonen meer gedragsproblemen dan meisjes) (Menting et al. 2013). Het is dan ook van belang om de unieke invloed van de ernst van probleemgedrag en het geslacht van het kind in één studie te onderzoeken.

\section{SES}

Ouderinterventies lijken minder effectief voor economisch achtergestelde gezinnen (d.w.z. lage SES) (zie meta-analyse van Lundahl et al. 2006). Uit een andere metaanalyse blijkt echter dat economisch achtergestelde gezinnen - wanneer er voor de ernst van probleemgedrag bij aanvang van de interventie wordt gecontroleerd - evenveel baat hebben bij ouderinterventies als economisch welgestelde gezinnen (Leijten et al. 2013). SES en de ernst van probleemgedrag lijken dus samen te hangen, waardoor de unieke invloed van deze moderatoren op de effectiviteit van ouderinterventies tot nu toe onduidelijk is.

\section{Gezinssamenstelling}

Alleenstaande ouders profiteren mogelijk minder van ouderinterventies dan tweeoudergezinnen (Griffin et al. 2000). Deze bevinding is echter waarschijnlijk afhankelijk van andere factoren, zoals SES. Alleenstaande ouders met een lage SES zijn wellicht minder goed in staat om interventiesessies bij te wonen door een gebrek 
aan een sociaal netwerk en economische middelen, zoals vervoer en kinderopvang (Fossum et al. 2009; Kazdin 1995; Reyno en McGrath 2006; maar zie Gardner et al. (2010) voor tegenstrijdige resultaten). Ook de gezinssamenstelling hangt dus wellicht samen met andere moderatoren (specifiek SES en het aantal sessies dat ouders bijwonen).

\section{Aantal interventiesessies waaraan ouders deelnemen}

Meta-analyses van Wilson en Lipsey (2001) en Menting et al. (2013) suggereren dat het aantal bijeenkomsten dat ouders bijwonen bepalend is voor de effectiviteit van een ouderinterventie. In de bijeenkomsten leren ouders specifieke opvoedingsvaardigheden en hoe zij deze kunnen toepassen in alledaagse situaties binnensen buitenshuis. Het missen van een of meer bijeenkomsten betekent dus dat zij specifieke inhoud missen, evenals het leerproces dat nodig is om zich de in de sessies behandelde opvoedingsvaardigheden eigen te maken en vervolgens toe te passen in de thuissituatie.

\section{Beperkingen van eerder onderzoek}

Uit de literatuur blijkt dat de richting evenals de unieke bijdragen (versus de gedeelde bijdrage) van de mogelijke moderatoren aan de effectiviteit van IY, en individuele verschillen hierin, nog onduidelijk zijn (zie Weersing en Weisz 2002). De verschillende moderatoren zijn daarnaast vaak los van elkaar onderzocht in relatief kleine steekproeven (gemiddeld 95 gezinnen in de meta-analyse van Menting et al. 2013). Dit zijn belangrijke tekortkomingen van eerder onderzoek, omdat deze moderatoren juist vaak met elkaar samenhangen. Een kleine steekproef leidt tot een lagere power en hiermee tot een groter risico op zowel type 1-fouten (d.w.z. onjuist concluderen dat er een effect is) als type 2-fouten (d.w.z. onjuist concluderen dat er geen effect is). Dit geldt des te meer voor moderatieanalyses, omdat de steekproef hierbij wordt opgedeeld in meerdere subgroepen (Sullivan en Feinn 2012). Een strenge procedure voor het toetsen van de effectiviteit van ouderinterventies is daarom noodzakelijk.

Een andere belangrijke beperking van eerder onderzoek is dat de meeste studies zijn gebaseerd op ouderrapportage over zowel het eigen opvoedgedrag als het gedrag van hun kind. Deze gegevens kunnen echter vertekend zijn (Sessa et al. 2001; Stifter et al. 2008). Observaties hebben belangrijke methodologische voordelen ten opzichte van vragenlijsten, waaronder een zekere mate van objectiviteit (Daley et al. 2014; Scott 2001; Sonuga-Barke et al. 2013). De huidige studie toetst daarom de effectiviteit van IY met zowel vragenlijstdata als observaties. Daarnaast wordt de mogelijke invloed van eerder onderzochte moderatoren getoetst in een relatief grote preventiesteekproef, daarbij gebruikmakend van één analysemodel, zodat er gecontroleerd kan worden voor de eventuele samenhang tussen moderatoren. 


\section{Methode}

\section{Design}

De huidige studie bestond uit een preventieve gerandomiseerde gecontroleerde trial (RCT) met twee condities (interventie versus controle) en drie meetmomenten (voormeting, nameting, follow-up na 4 maanden) en was opgebouwd uit twee fasen. In de eerste fase werden gezinnen geworven en gescreend via twee $\mathrm{Ge}$ meentelijke Gezondheidsdiensten (GGD's). Alle gezinnen met kinderen in de leeftijd van 4-8 jaar $(n=20.048)$ ontvingen een gepersonaliseerde informatiebrief, inclusief toestemmingsformulier en screeningsvragenlijst (Eyberg Child Behavior Inventory; Eyberg en Pincus 1999). Gezinnen kregen een vergoeding van $€ 7,50$ als zij binnen twee weken de vragenlijst ingevuld retourneerden. In totaal werden 5.876 vragenlijsten tijdig geretourneerd $(22,52 \%)$. Kinderen die op de gedragsscreeningslijst boven het 75e percentiel van hun cohort scoorden, kwamen in aanmerking voor deelname aan het onderzoek $(n=1.524)$.

In de tweede fase werden alle gezinnen die in aanmerking kwamen voor het onderzoek uitgenodigd voor deelname aan de RCT: Observational Randomized Trial on Childhood Differential Susceptibility (ORCHIDS-studie) (Chhangur et al. 2012). Van de gezinnen die in aanmerking kwamen, werd ongeveer $60 \%$ telefonisch bereikt $(n=850)$, en $46 \%$ van de bereikte gezinnen deed uiteindelijk mee met het onderzoek (zie fig. 1 voor een overzicht van deze selectieprocedure). Gezinnen die uiteindelijk geïncludeerd werden deden mee aan drie meetmomenten: een voormeting voorafgaand aan de randomisatie, een nameting direct na de interventie (4 maanden na voormeting) en een follow-up 4 maanden na de interventie (8 maanden na voormeting). Randomisatie voor controle- en interventieconditie (1:1) vond plaats nadat ouders toestemming hadden gegeven voor het onderzoek en de eerste meting had plaatsgevonden. Gezinnen in de interventiegroep kregen tussen de voormeting en de nameting IY aangeboden. Deelnemers in de controlegroep kregen geen IY aangeboden, maar waren gedurende het onderzoek vrij om hulp te zoeken wanneer nodig (eventueel ondersteund door de onderzoekers). Op het moment van de voormeting waren zowel de onderzoekers als ouders dus niet op de hoogte van (d.w.z. blind voor) de groepsindeling.

\section{Deelnemers}

In totaal deden 387 ouder-kinddyades mee aan de RCT (waarvan 190 in de controlegroep en 197 in de interventiegroep). Kinderen waren bij aanvang van de studie tussen de 4-8 jaar (Mleeftijd =6,31, SD=1,33) en meestal geboren in Nederland $(97,4 \%)$, en ongeveer de helft was jongen $(55,30 \%)$. Deelnemende ouders (91\% moeders) waren bij aanvang van de studie tussen de $23-51$ jaar oud (Mleeftijd $=38,10, S D=4,84)$ en meestal geboren in Nederland ( $86 \%$ van de moeders, $84 \%$ van de vaders), en ongeveer de helft was hoogopgeleid (zie tab. 1 en 2 voor demografische en beschrijvende statistieken). Een a-priori-poweranalyse ge- 


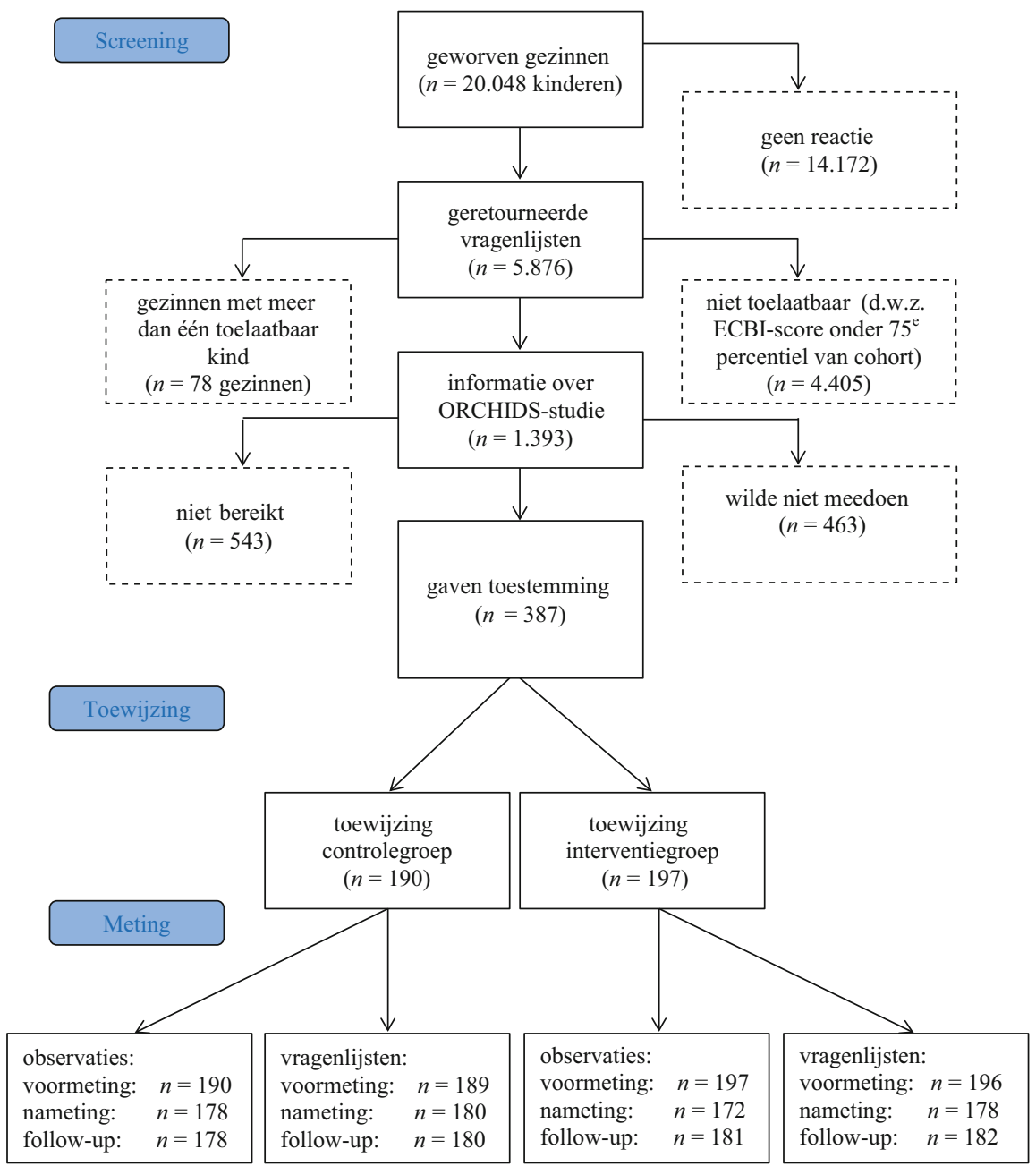

Figuur 1 Overzicht van de selectieprocedure van de deelnemers

baseerd op acht uitkomstmaten en zes voorspellers (conditie, de moderatoren en de interacties tussen conditie en moderatoren) met een klein effect, toonde aan dat data van 311 gezinnen al een power van 0,90 zou moeten opleveren om effecten te vast te stellen (G*Power 3; Faul et al. 2007).

\section{Randomisatiecheck}

Deelnemers aan de interventie- of controleconditie verschilden niet significant van elkaar in leeftijd (kind en ouder), geslacht (kind en ouder), geboorteland (kind en ouder), opleidingsniveau, beroepsstatus, burgerlijke staat, religie of gerapporteerd 
Tabel 1 Demografische gegevens van steekproef

\begin{tabular}{|c|c|c|c|c|}
\hline \multirow{2}{*}{ leeftijd kind $(M ; S D)$} & & $\begin{array}{l}\text { conditie } \\
\text { totaal } \\
(n=387)\end{array}$ & $\begin{array}{l}\mathrm{E} \\
(n=197)\end{array}$ & $\begin{array}{l}\text { C } \\
(n=190)\end{array}$ \\
\hline & & 6,$31 ; 1,33$ & 6,$3 ; 1,36$ & 6,$32 ; 1,29$ \\
\hline \multirow[t]{2}{*}{ geslacht kind } & jongen & 55,3 & 57,9 & 52,6 \\
\hline & meisje & 44,7 & 42,1 & 47,4 \\
\hline \multirow[t]{2}{*}{ geboorteland moeder } & Nederland & 86 & 84,8 & 87,4 \\
\hline & overig & 14 & 15,2 & 12,6 \\
\hline \multirow[t]{2}{*}{ geboorteland vader } & Nederland & 84 & 82,8 & 85,8 \\
\hline & overig & 16 & 17,2 & 14,2 \\
\hline \multicolumn{2}{|c|}{ leeftijd deelnemende ouder $(M ; S D)$} & $\begin{array}{l}38,10 \\
4,84\end{array}$ & 38,$02 ; 4,9$ & $\begin{array}{l}38,17 \\
4,79\end{array}$ \\
\hline \multirow{2}{*}{$\begin{array}{l}\text { geslacht deelnemende } \\
\text { ouder }\end{array}$} & $\operatorname{man}$ & 8,00 & 7,6 & 8,4 \\
\hline & vrouw & 91 & 92,4 & 91,6 \\
\hline \multirow[t]{3}{*}{ opleiding moeder } & laag & 21,2 & 23,5 & 18,9 \\
\hline & midden & 27,5 & 27 & 27,9 \\
\hline & hoog & 50,5 & 48 & 52,6 \\
\hline \multirow[t]{3}{*}{ opleiding vader } & laag & 25,6 & 25 & 26,3 \\
\hline & midden & 26,2 & 28,1 & 50,3 \\
\hline & hoog & 45,6 & 44,9 & 46,4 \\
\hline \multicolumn{5}{|c|}{ werkstatus deelnemende ouder } \\
\hline \multirow{5}{*}{$\begin{array}{l}\text { - werkend } \\
\text { - niet werkend: }\end{array}$} & & 73,6 & 75,6 & 71,6 \\
\hline & & 26,4 & 24,4 & 28,4 \\
\hline & zonder werk & 23,3 & 19,6 & 26,4 \\
\hline & huisvader/moeder & 44,4 & 43,5 & 45,5 \\
\hline & overig & 32,3 & 36,9 & 28,1 \\
\hline \multicolumn{5}{|c|}{ huwelijkse staat deelnemende ouder: } \\
\hline & getrouwd/samenwonend & 87 & 85,7 & 88,4 \\
\hline & vrijgezel & 8,8 & 11,2 & 6,3 \\
\hline & overig & 4,1 & 3,1 & 5,3 \\
\hline \multicolumn{2}{|c|}{ kinderen in het gezin $(M ; S D)$} & 2,$23 ; 0,82$ & 2,$3 ; 0,87$ & 2,$24 ; 0,78$ \\
\hline \multirow[t]{4}{*}{ geloof } & christelijk & 39,15 & 42,3 & 36,85 \\
\hline & islamitisch & 5,45 & 5,1 & 5,75 \\
\hline & geen & 34,2 & 34,05 & 33,45 \\
\hline & overig & 21,2 & 18,55 & 23,95 \\
\hline
\end{tabular}

probleemgedrag bij aanvang van de studie ( $p$ 's $>0,06)$ (zie tab. 1). Het geobserveerde negatieve gedrag van het kind verschilde significant tussen de twee condities $(F(1,1,61)=5,40, p=0,02)$ : kinderen in de interventieconditie scoorden gemiddeld hoger op geobserveerd negatief gedrag $(M=0,52 ; S D=0,62)$ dan kinderen in de controleconditie $(M=0,39 ; S D=0,46)$. In alle analyses werd gecontroleerd voor dit verschil. 


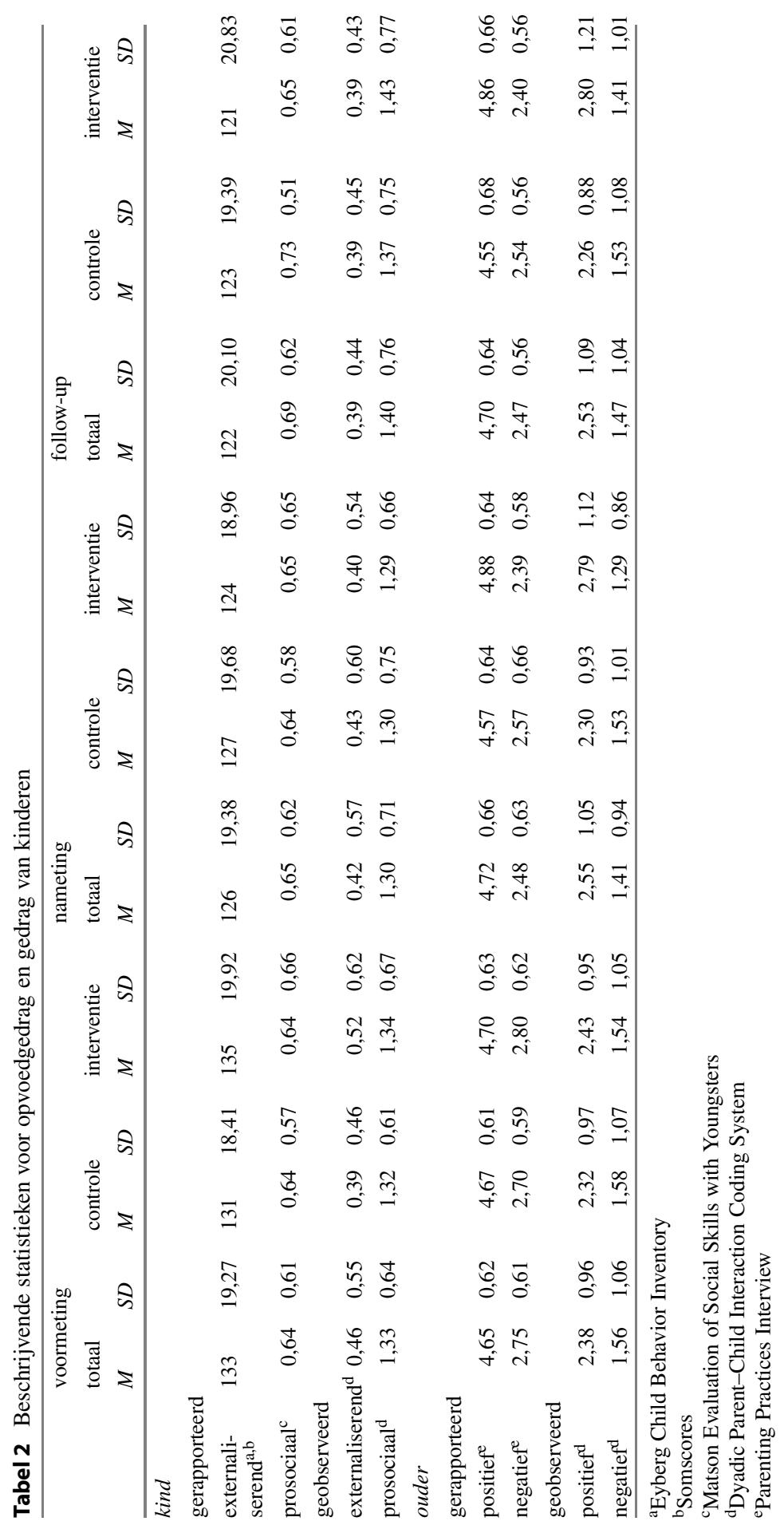




\section{Uitval}

Tijdens het onderzoek vielen in totaal 28 gezinnen uit. Er was geen verschil in uitval tussen de twee condities $(p=0,19)$. De gezinnen die uitvielen verschilden niet van gezinnen die alle meetmomenten meededen tijdens de voormeting ( $p$ 's $>0,09)$, met uitzondering van burgerlijke staat $(\chi 2(4, n=386)=11,30, p=0,02)$ en opleidingsniveau $(\chi 2(8, n=386)=21,52, p<0,01)$. Ouders die deelnamen aan de drie meetmomenten waren vaker getrouwd ( $71 \%$ vs. $51 \%$ getrouwd) en hoger opgeleid ( $81 \%$ vs. $51 \%$ hoog opgeleiden) dan ouders die gedurende de studie uitvielen.

\section{Procedure}

Tijdens de voormeting werd aan ouders gevraagd om een digitale vragenlijst in te vullen en werden ouder en kind gefilmd tijdens een gestructureerde spelsituatie (Chhangur et al. 2012). Tijdens de nameting en de follow-up werd deze procedure herhaald. De deelnemende gezinnen ontvingen $€ 20,-$ voor de eerste twee huisbezoeken en $€ 40$,- voor het derde huisbezoek. De procedure werd goedgekeurd door de Medisch Ethische Toetsingscommissie van het UMC Utrecht (METC UMCU, protocol nummer $11-320 / \mathrm{K})$.

\section{Vragenlijsten}

\section{Opvoedgedrag: Parenting Practices Interview (PPI)}

De PPI meet opvoedvaardigheden van ouders met kinderen tussen de 6-12 jaar (Webster-Stratton 2001a). De PPI bestaat uit vijftien onderdelen, die meerdere vragen en stellingen (items) bevatten over hoe ouders omgaan met gewenst en ongewenst gedrag van hun kind. In totaal werden er vier algemene schalen gebruikt: Hard en inconsequent straffen (15 items, bijv. 'dreigen maar niet te straffen'), Positieve verbale discipline (9 items, bijv. 'probleem bespreken met kind'), Lijfstraffen (6 items, bijv. 'slaan bij ongewenst gedrag') en Prijzen en belonen (11 items, bijv. 'knuffel of een compliment geven bij gewenst gedrag'). Om positief opvoedgedrag te meten werden de schalen Positieve verbale discipline en Prijzen en belonen samengenomen. Om negatief opvoedgedrag te meten werden de schalen Harde en inconsequente discipline en Lijfstraffen samengenomen. De betrouwbaarheid van beide schalen was goed op alle metingen (positief opvoedingsgedrag $\alpha>0,70$; negatief opvoedingsgedrag $\alpha>0,78$ ).

\section{Externaliserende gedragsproblemen kind: Eyberg Child Behavior Inventory (ECBI)}

De ECBI meet externaliserende gedragsproblemen (dwars en opstandig gedrag) bij kinderen tussen de 2-16 jaar (Eyberg en Pincus 1999). We gebruikten de ECBI- 
intensiteitsschaal bestaande uit 36 items, waarbij de frequentie van het probleemgedrag (bijv. 'gedraagt zich opstandig als hij/zij gevraagd wordt om iets te doen') werd gemeten op een zevenpuntsschaal $(1=$ nooit tot $7=$ altijd $)$. De betrouwbaarheid van de intensiteitsschaal was goed voor alle drie de meetmomenten $(\alpha>0,84)$.

\section{Gewenst gedrag kind: Matson Evaluation of Social Skills with Youngsters (MESSY)}

De MESSY meet sociaal gedrag bij schoolgaande kinderen (Matson et al. 1983). De vragenlijst bestaat uit 62 items gemeten op een vijfpuntsschaal $(1=$ helemaal niet tot $5=$ zeer veel) en beoordeelt de frequentie van prosociaal en agressief gedrag in een reeks van sociale situaties. In de huidige studie werd de schaal Gepast sociaal gedrag gekozen om gewenst/prosociaal gedrag te meten. De schaal bestaat uit twintig items (bijv. 'komt op voor vrienden') en de betrouwbaarheid was goed op alle drie de meetmomenten $(\alpha>0,88)$.

\section{Observaties}

\section{Dyadic Parent-Child Interaction Coding System (DPICS)}

Het DPICS is een coderingsysteem voor het meten van de kwaliteit van sociale interacties (Robinson en Eyberg 1981; Webster-Stratton 1989). Ouder en kind werden gedurende 20 minuten geobserveerd tijdens een gestructureerde spelsituatie. De procedure bestond uit 4 periodes van ieder 5 minuten: 1) vrij spel (wennen aan de situatie en opnameapparatuur); 2) kindgericht spelen (kind kiest speelgoed en heeft leiding); 3) oudergericht spelen (ouder kiest speelgoed en heeft leiding); en 4) opruimen (ouder geeft kind de opdracht op te ruimen). Voor de laatste drie periodes werd positief en negatief gedrag van ouder en kind gecodeerd aan de hand van verschillende categorieën: 7 categorieën voor positief oudergedrag (bijv. prijzen), 6 categorieën voor negatief oudergedrag (bijv. negatief geformuleerde opdrachten), 5 categorieën voor positief gedrag van het kind (bijv. uitvoering van opdrachten) en 4 categorieën voor negatief gedrag van het kind (bijv. niet uitvoeren van opdrachten). De betrouwbaarheid van de schalen was $\alpha>0,60$ voor positief opvoedgedrag, $\alpha>0,67$ voor negatief opvoedgedrag, $\alpha>0,49$ voor positief gedrag van het kind en $\alpha>0,56$ voor negatief gedrag van het kind. Dit is vergelijkbaar met eerdere studies (Posthumus et al. 2012).

De spelsituaties werden gecodeerd door getrainde onderzoeksassistenten (masterstudenten pedagogiek). Zij waren blind voor de conditie van de gezinnen en het betreffende meetmoment. Om de interbeoordelaarsbetrouwbaarheid te meten zijn 237 van de 1.161 observaties (20\%) door twee onafhankelijke codeurs gecodeerd. De interbeoordelaarsbetrouwbaarheid was voldoende tot goed voor alle constructen $(0,70$ tot 0,97$)$. 


\section{Interventie: Pittige Jaren / The Incredible Years BASIS-programma}

De ouderinterventie IY beoogt in de context van geïndiceerde preventie (zoals in de huidige studie) of in een behandelingscontext een goede en warme relatie tussen ouder en kind te creëren door middel van het aanleren van positieve opvoedvaardigheden (bijv. kindgericht spelen, sociale en emotiecoaching, prijzen en belonen) en door middel van het verminderen van het gebruik van negatieve opvoedvaardigheden (bijv. het kritisch en inconsequent zijn) (Webster-Stratton 2001b). IY is een groepsinterventie bestaande uit veertien wekelijkse sessies (en een 'booster'sessie een maand na afronding van het programma). Het programma begint met de focus op positieve opvoedvaardigheden, zoals spelen met je kind, prijzen en belonen, gevolgd door grenzen stellen en omgaan met ongewenst gedrag. Tijdens de sessies worden bestaande videofragmenten van ouder-kindinteracties bekeken en bediscussieerd, nieuwe vaardigheden geoefend in rollenspellen en brainstormsessies gehouden. Elke groep werd geleid door twee groepstrainers, waarbij de hoofdtrainer een gecertificeerd IY-trainer was (twee trainers behaalden certificering tijdens de studie). IY maakt gebruik van een collaboratieve aanpak, wat betekent dat groepstrainers optreden als procesbegeleiders en niet zozeer als experts; zij moedigen ouders aan om (samen) problemen op te lossen en waarborgen de focus op de elementen die centraal staan in IY.

\section{Interventie-integriteit}

Er werden in totaal veertien IY-interventiegroepen gestart (bestaande uit 8-15 ouders), die plaatsvonden in Almere, Amersfoort of Maarssen. Ouders in de interventiegroep namen deel aan gemiddeld $11,01(S D=3,69)$ van de 15 sessies. Van deze ouders deed $74 \%$ mee aan minimaal 10 sessies en $84 \%$ aan ten minste de helft van de sessies. De door trainers ingevulde checklists lieten zien dat gemiddeld $86 \%$ van de gestandaardiseerde basiselementen werd uitgevoerd (waaronder brainstormsessies en rollenspelen) en gemiddeld zes filmfragmenten per sessie werden getoond. Uit onderzoek blijkt dat minimaal $60 \%$ van de basiselementen uitgevoerd moeten worden (minimale integriteit) om de beoogde effecten te garanderen (Durlak en DuPre 2008).

\section{Analyses}

Latent growthcurve modelling (LGCM) in Mplus (Muthén en Muthén 2010) werd gebruikt om de ontwikkeling (d.w.z. groeicurve) van geobserveerd en gerapporteerd gedrag van ouder en kind te meten voor de periode van de voormeting, nameting en follow-up. De conditie (controle versus interventie) waarin gezinnen waren gerandomiseerd werd hierbij gebruikt om de verandering van de uitkomstmaten in de loop van de studie (de groeicurve of slope) te voorspellen, waarbij gecontroleerd wordt voor variatie aan het begin van de studie (de intercept). De 
software geeft aan dat het model van de analyse goed bij de data past wanneer de root mean square error of approximation (RMSEA) $<0,05$ is en de confirmatory fit index (CFI) $>0,95$ is (Hu en Bentler 1999). Alle modellen in deze studie hadden een voldoende tot goede modelfit (zie tab. 3). De grootte van de effecten werd weergegeven met Cohens $d$, waarbij $\mathrm{d} \geq 0,20$ een klein effect is, $\geq 0,50$ een middelgroot effect en $\geq 0,80$ een groot effect.

Van de interventiegroep hebben 44 ouders besloten om niet deel te nemen aan het programma of om nooit een sessie bij te wonen. Omdat er tijdens de voormeting geen verschil werd gevonden tussen de niet-deelnemers en deelnemers ( $p$ 's $>0,09$ ), werden de 44 IY-toegewezen ouders die geen sessies bijwoonden alsnog opgenomen in de analyses. In totaal hebben we acht unieke uitkomstmaten bekeken (vier gerapporteerd door ouders; vier geobserveerd) in een 'intention-totreat'-analyse (alle gezinnen die voor de interventiegroep waren geloot). In totaal zijn er acht analyses uitgevoerd voor het bekijken van de acht uitkomstmaten en acht analyses voor het bekijken van de invloed van de vijf moderatoren op deze uitkomstmaten. In deze laatste analyses zijn de moderatoren simultaan in een model geanalyseerd. De correctie met de Benjamini-Hochberg False Discovery Rate (Benjamini en Hochberg 2005) werd gebruikt om de $p$-waarden te corrigeren voor kans-kapitalisatie bij het uitvoeren van meerdere toetsen. Na het onderzoeken van de interventie-effecten werden de moderatoren onderzocht aan de hand van acht multivariate LGCM-mixture-modellen, waarbij gecontroleerd werd voor de onderlinge samenhang tussen de moderatoren.

\section{Resultaten}

\section{Effectiviteit}

\section{Externaliserend probleemgedrag}

De conditie waarin gezinnen waren gerandomiseerd had in de loop van de studie een significant effect op de verandering van externaliserend probleemgedrag (de groeicurve of slope) $\left(B_{1}=-0,175, p<0,001, p<0,001, d=0,31\right)$. Kinderen van ouders in de interventiegroep lieten bij de nameting en follow-up een grotere afname van dit gedrag zien (zie tab. 3). Conditie bleek geen significant effect te hebben op de slope van geobserveerd probleemgedrag $\left(B_{1}=-0,063, p=n s\right.$. $)$. Dit betekent dat IY wel effectief is in het verminderen van probleemgedrag gerapporteerd door ouders, maar niet in het verminderen van geobserveerd probleemgedrag.

\section{Prosociaal gedrag van het kind}

Conditie had geen significant effect op de slope van ouder-gerapporteerd gewenst/ prosociaal gedrag $\left(B_{l}=0,019, p=n s\right.$. $)$ of op de slope van geobserveerd gewenst/ prosociaal gedrag $\left(B_{l}=0,008, p=n s\right.$.) (zie tab. 3$)$. Dit betekent dat IY geen effect heeft op gewenst/prosociaal gedrag van kinderen. 


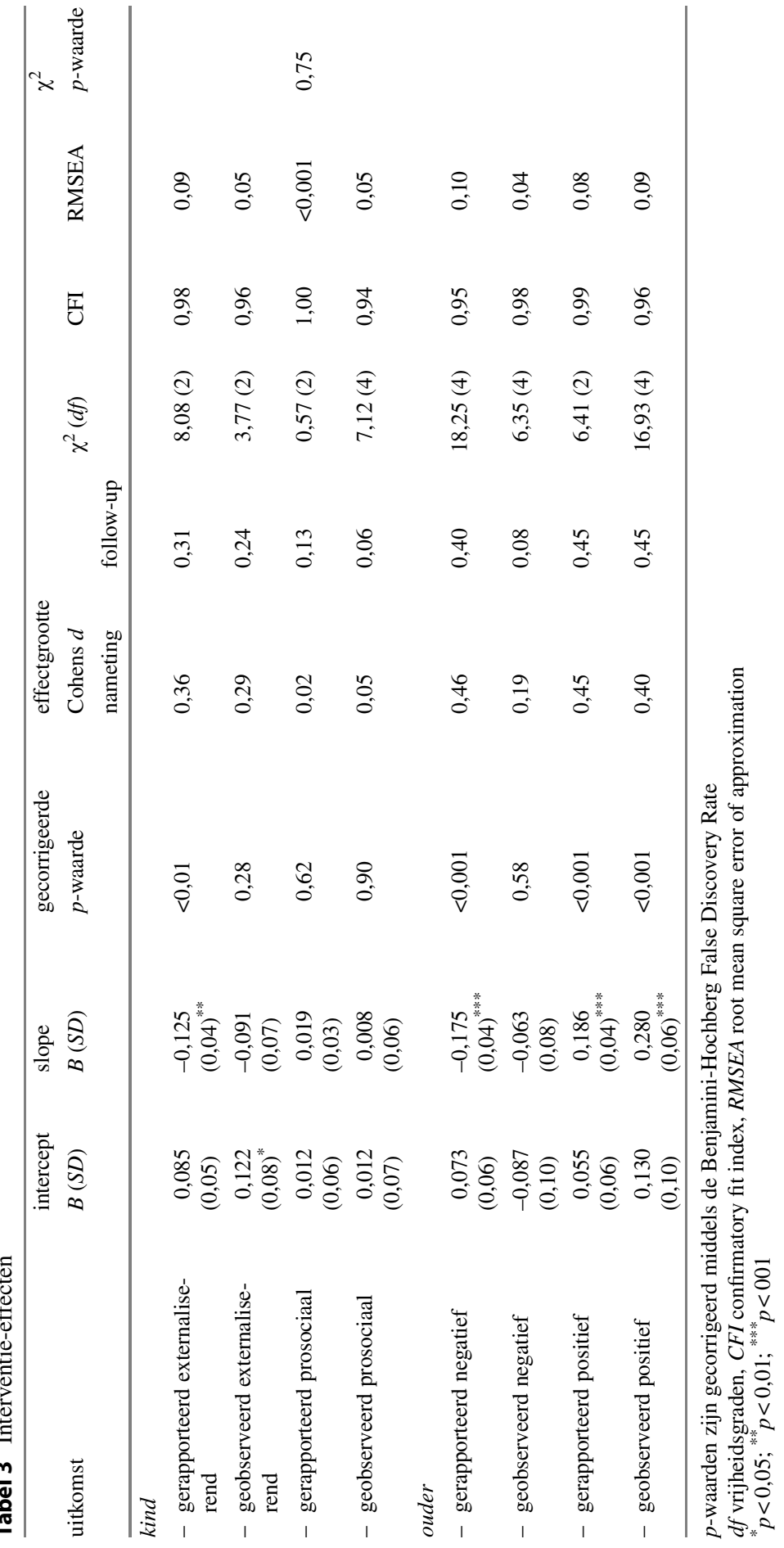




\section{Negatief opvoedgedrag}

Conditie had een significant effect op de slope van ouder-gerapporteerd negatief opvoedgedrag $\left(B_{l}=-0,175, p<0,001, p<0,001, d=0,40\right)$. Ouders in de interventiegroep lieten een grotere afname van dit gedrag zien dan ouders in de controlegroep. Dit betekent dat de interventie een positief effect heeft op gerapporteerd negatief opvoedgedrag. Conditie bleek geen significant effect te hebben op de slope van geobserveerd negatief opvoedgedrag $\left(B_{I}=-0,063, p=n s\right.$. $)$. Dit betekent dat de interventie geen effect heeft op geobserveerd negatief opvoedgedrag.

\section{Positief opvoedgedrag}

Conditie had een significant effect op de slope van ouder-gerapporteerd positief opvoedgedrag $\left(B_{I}=0,186, p<0,001, d=0,45\right)$ en op de slope van geobserveerd positief opvoedgedrag $\left(B_{1}=0,280, p<0,001, d=0,45\right)$. Ouders in de interventiegroep lieten een grotere toename van dit gedrag zien dan ouders in de controlegroep. Dit betekent dat IY een positief effect heeft op zowel gerapporteerd als geobserveerd positief opvoedgedrag.

\section{Moderatie-effecten}

Tab. 4 toont de correlaties tussen de moderatoren. De ernst van het externaliserende probleemgedrag was significant gecorreleerd met geslacht $\mathrm{r}(r=-0,21, p<0,05)$ en gezinssamenstelling $(r=-0,21, p<0,05)$, wat aangeeft dat alleenstaande ouders (versus getrouwde of samenwonende ouders) en ouders van jongens (versus meisjes) meer probleemgedrag rapporteren. SES was significant gecorreleerd met gezinssamenstelling $(r=-0,13, p<0,01)$ en het aantal sessies dat ouders bijwonen $(r=0,16, p<0,05)$, wat aangeeft dat ouders met een lage SES vaker alleenstaand zijn en gemiddeld minder sessies bijwoonden wanneer zij in de interventiegroep zaten. Zoals gepland hebben wij in de analyses rekening gehouden met deze samenhang om zo te controleren voor mogelijke gezamenlijke effecten van deze variabelen.

Tabel 4 Correlaties

\begin{tabular}{|c|c|c|c|c|c|}
\hline & 1 & 2 & 3 & 4 & 5 \\
\hline 1. ernst van gedragsproblemen bij aanvang & - & & & & \\
\hline 2. geslacht kind (jongens \%) & $-0,205^{* *}$ & - & & & \\
\hline 3. sociaaleconomische status & 0,031 & 0,057 & - & & \\
\hline 4. gezinssamenstelling (alleenstaande ouder \%) & $0,105^{*}$ & $-0,058$ & $-0,134^{* *}$ & - & \\
\hline 5. aantal sessies door ouder bijgewoond ${ }^{\mathrm{a}}$ & 0,044 & $-0,058$ & $0,163^{*}$ & $-0,046$ & - \\
\hline
\end{tabular}

Geslacht: $0=$ jongen; $1=$ meisje; gezinssamenstelling: $0=$ samenwonend; $1=$ alleenstaande ouder ${ }^{a}$ Alleen van toepassing in de interventiegroep ${ }^{*} p<0,05 ;{ }^{* *} p<0,01$ 


\section{Ernst van externaliserend probleemgedrag bij aanvang}

De ernst van probleemgedrag bij aanvang van de interventie was voor de interventiegroep een voorspeller van de slope van ouder-gerapporteerd probleemgedrag $\left(B_{l}=-0,121, p=0,04\right)$, maar niet voor de controlegroep $\left(B_{l}=-0,031, p=n s\right.$. . Ouders in de interventiegroep die bij de screening meer probleemgedrag rapporteerden, rapporteerden tijdens de nameting en follow-up ook een grotere afname van probleemgedrag (zie tab. 5). Maar het effect van de ernst bij aanvang (d.w.z. de coëfficiënt) op probleemgedrag bleek voor de interventiegroep uiteindelijk niet significant groter te zijn dan voor de controlegroep $(t(374)=1,15, p=n s$. $)$. De ernst van probleemgedrag bij aanvang van de interventie modereerde dus niet het interventie-effect.

\section{Geslacht van het kind}

Geslacht van het kind was voor de interventiegroep een voorspeller van de slope van geobserveerd gewenst/prosociaal gedrag $\left(B_{l}=0,203, p=0,03\right)$, maar niet voor de controlegroep $\left(B_{l}=0,015, p=n s\right.$. $)$. In de interventiegroep lieten meisjes een grotere toename van gewenst/prosociaal gedrag zien dan jongens. Maar het effect van geslacht bleek uiteindelijk voor de interventiegroep niet significant groter te zijn dan voor de controlegroep $(t(374)=0,27, p=n s$.). Geslacht van het kind modereerde daarmee geen interventie-effecten.

\section{SES}

SES (opleiding van de ouders) was voor de controlegroep een voorspeller van de slope van gerapporteerd negatief opvoedgedrag $\left(B_{1}=0,087, p=0,03\right)$, maar niet voor de interventiegroep $\left(B_{l}=0,005, p=n s\right.$.) (zie tab. 5). In de controlegroep rapporteerden gezinnen met een lage SES een sterkere toename van negatief opvoedgedrag dan gezinnen met een hogere SES. Maar het effect van SES bleek uiteindelijk voor de controlegroep niet significant groter te zijn dan voor de interventiegroep $(t=1,45, d f=364, p=n s$.). Ook vonden we dat SES zowel voor de controlegroep $\left(B_{1}=-0,156, p=0,04\right)$ als voor de interventiegroep $\left(B_{l}=0,000\right.$, $p<0,001)$ een voorspeller was voor de slope van geobserveerd probleemgedrag. Dit betekent dat gezinnen met een lage SES een sterkere toename in probleemgedrag rapporteerden dan gezinnen met een hoge SES, ongeacht of ze in de interventie- of de controlegroep zaten. Maar ook hier bleek het effect van SES voor de interventiegroep uiteindelijk niet significant groter te zijn dan voor de controlegroep $(t=1,56$, $d f=374, p=n s$.). Daarnaast was SES voor de interventiegroep een voorspeller van de slope van geobserveerd prosociaal gedrag van het kind $\left(B_{l}<0,000, p<0,001\right)$, maar niet voor de controlegroep $\left(B_{l}=-0,020, p=n s\right.$.). Wederom bleek dit effect voor de interventiegroep niet significant groter te zijn dan voor de controlegroep $(t=0,33, d f=374, p=n s$. $)$. Er werd dus geen moderatie-effect van SES gevonden. 


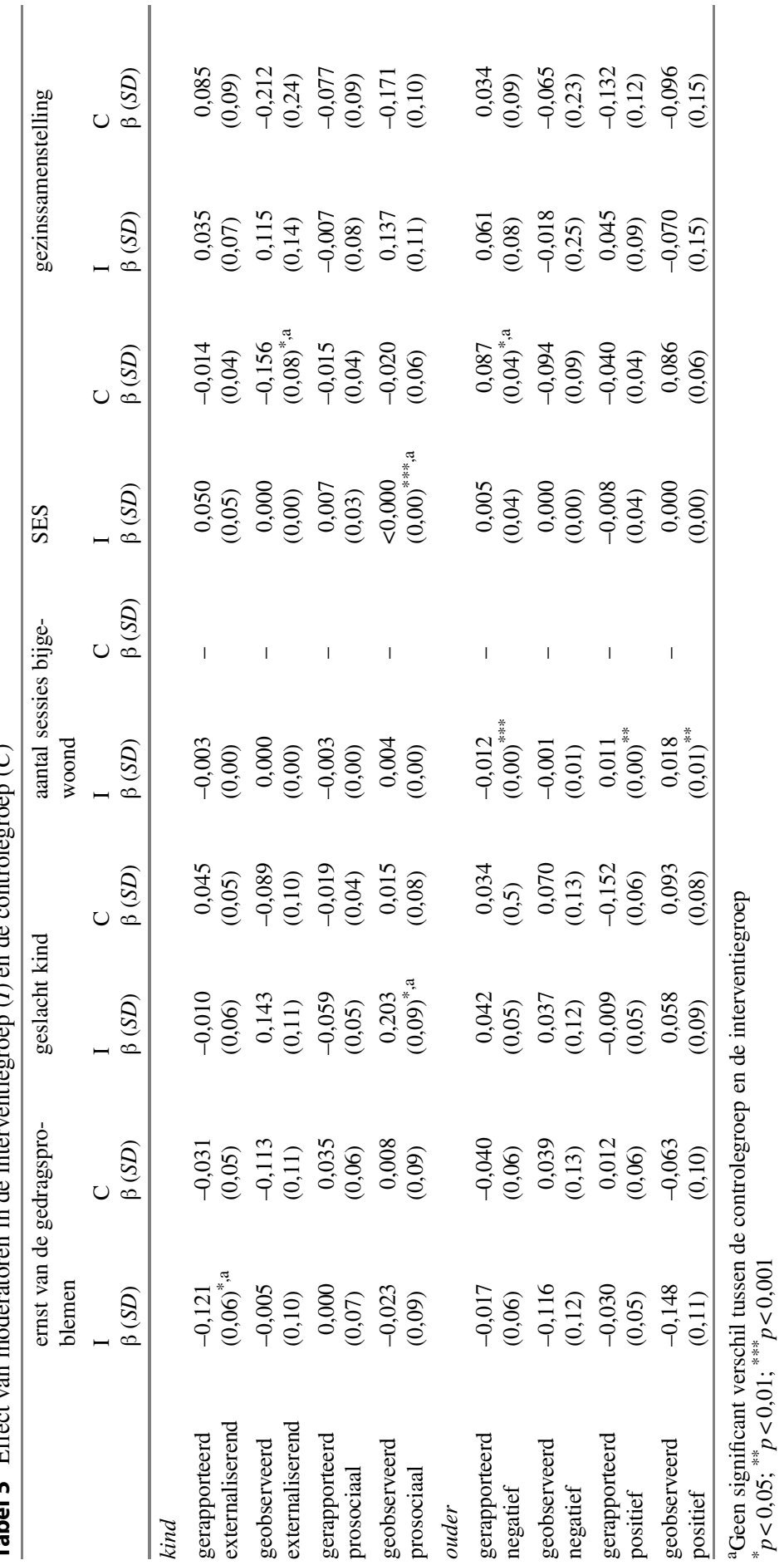




\section{Gezinssamenstelling}

Gezinssamenstelling was geen voorspeller van de slope van de uitkomstmaten (tab. 5). Dit betekent dat alleenstaande ouders en tweeoudergezinnen evenveel profiteerden van IY.

\section{Aantal interventiesessies waaraan ouders deelnemen}

Aantal bijgewoonde IY-sessies was voor de interventiegroep een voorspeller voor de slope van ouder-gerapporteerd negatief opvoedgedrag $\left(B_{1}=-0,012, p<0,001\right.$, tab. 5), ouder-gerapporteerd positief opvoedgedrag $\left(B_{l}=0,011, p=0,001\right)$ en geobserveerd positief opvoedgedrag $\left(B_{1}=0,018, p=0,001\right)$. Ouders die meer IYsessies bijwoonden, rapporteerden een grotere afname van negatief en een grotere toename van positief opvoedgedrag. Daarnaast lieten zij een grotere toename van geobserveerd positief opvoedgedrag zien dan ouders die minder IY-sessies volgden.

\section{Discussie}

Deze studie toetste met een grote gerandomiseerde gecontroleerde trial (RCT, $N=387$ ) de effectiviteit van de preventieve oudertraining Pittige Jaren (The Incredible Years; IY) voor het verminderen van externaliserende gedragsproblemen van kinderen tussen de 4 en 8 jaar oud. Tevens toetste deze studie de unieke effecten van (en samenhang tussen) meerdere sociaal-demografische en interventiespecifieke moderatoren die deze effectiviteit mogelijk beïnvloeden: de ernst van het probleemgedrag bij aanvang van de interventie, het geslacht van het kind, de SES, de gezinssamenstelling en het aantal sessies dat ouders bijwonen.

Onze resultaten tonen aan dat IY succesvol is in het verminderen van ouder-gerapporteerd probleemgedrag (nameting: $d=0,36$; follow-up: $d=0,31$ ), het verminderen van ouder-gerapporteerd negatief opvoedgedrag (nameting: $d=0,46$; followup: $d=0,40$ ) en het verhogen van zowel ouder-gerapporteerd (nameting: $d=0,45$; follow-up: $d=0,45$ ) als geobserveerd positief opvoedgedrag (nameting: $d=0,40$; follow-up: $d=0,45$ ). Hoewel de effectgroottes relatief klein zijn, zijn ze vergelijkbaar met effectgroottes gevonden in een meta-analyse naar IY in een vergelijkbare geïndiceerde preventieve setting (Menting et al. 2013).

\section{Interventie-effecten: discrepantie tussen uitkomstmaten}

Er werden geen interventie-effecten gevonden op geobserveerd (externaliserend en prosociaal) gedrag van het kind. Dit is verrassend, omdat een recente metaanalyse van Menting et al. (2013) van 23 observatiestudies wel overtuigend bewijs vond voor effecten van IY op geobserveerd gedrag. Een mogelijke verklaring voor deze discrepantie ligt in het verschil in samenstelling van de DPICS-schalen, de 
relatieve lage betrouwbaarheid van de gebruikte DPICS-schalen, de lage spreiding die we vonden in middels DPICS geobserveerd gedrag, en het feit dat we streng hebben gecontroleerd voor kans-kapitalisatie (m.a.w. we hebben het vergroten van de kans op significante resultaten door de uitvoering van meerdere toetsen vermeden). Een andere mogelijke verklaring is het verschil in wat vragenlijsten en observaties precies meten. Bij de vragenlijsten wordt aan ouders gevraagd over een langere periode en in verschillende contexten over het gedrag van hun kind te rapporteren, terwijl bij de observaties het gedrag van het kind in een korte periode van 20 minuten wordt gemeten. Toekomstig onderzoek zou gebruik kunnen maken van uitgebreidere observatietechnieken, waarbij gedrag in verschillende situaties wordt bekeken, zoals bijvoorbeeld in de ochtend of tijdens het avondeten.

Eerder onderzoek laat zien dat verschillende informanten verschillende informatie over het gedrag van ouder en kind leveren. Recent meta-analytisch onderzoek laat bijvoorbeeld zien dat de samenhang tussen opvoedgedrag gerapporteerd door ouders en geobserveerd opvoedgedrag significant, maar zwak is $(r=0,17$; Hendriks et al. 2017). Deze samenhang neemt echter mogelijk verder af naarmate kinderen meer probleemgedrag vertonen (Moens et al. 2018). De discrepantie tussen de uitkomsten van deze studie gevonden met behulp van door ouders gerapporteerde maten en de geobserveerde maten kan wellicht deels verklaard worden door het feit dat de antwoorden die ouders tijdens de metingen geven aan allerlei invloeden onderhevig zijn (d.w.z. dat ouders een bias hebben). Ouders in de interventiegroep zijn bijvoorbeeld wellicht sneller geneigd een verbetering in het gedrag van hun kinderen te rapporteren dan ouders in de controlegroep, omdat zij veel tijd en energie in het verbeteren van hun opvoedgedrag hebben geïnvesteerd of omdat zij de therapeuten een plezier willen doen. Dit zou verklaren waarom ouders wel rapporteren dat het gedrag van hun kind is verbeterd, maar dit niet terug te zien is in observaties. Anderzijds laten ouder en kind zich tijdens de korte observaties mogelijk van hun beste kant zien, waardoor deze observaties zouden kunnen leiden tot een onderschatting van de problematiek. Hier lijkt in onze studie echter geen sprake van te zijn. Desalniettemin pleiten deze mogelijke vormen van bias ervoor om gedrag van ouders en kinderen op verschillende manieren te meten. Bijvoorbeeld door het gedrag niet alleen middels ouderrapportage en observaties te meten, maar ook personen die blind zijn voor de conditie te bevragen, zoals leerkrachten (Weisz en Kazdin 2010). Wat betreft IY blijkt uit een meta-analyse van studies naar IY dat de behandeleffecten volgens observaties, ouder- en leerkrachtbeoordelingen inderdaad verschillen, maar over het algemeen positief en van vergelijkbare grootte zijn (Menting et al. 2013).

We vonden wel een effect van IY op geobserveerd positief opvoedgedrag (maar niet op geobserveerd negatief opvoedgedrag). Een mogelijke verklaring hiervoor zou kunnen zijn dat een positieve verandering in opvoedgedrag eerder zichtbaar is dan een afname van negatief opvoedgedrag, specifiek wanneer geobserveerd door derden. IY investeert sterk in het versterken van de ouder-kindrelatie door de nadruk te leggen op het gebruik van positieve opvoedingsstrategieën (bijvoorbeeld spelen en prijzen/belonen). Bovendien is het wellicht gemakkelijker om ouders te stimuleren om gebruik te maken van, voor hen nieuwe, positieve opvoedings- 
strategieën dan om negatieve ouder-kindinteracties te doorbreken (zie echter de resultaten van Posthumus et al. 2012).

\section{Moderatie-effecten}

Het bleek de moeite waard om alle moderatoren in een analyse op te nemen, omdat deze inderdaad blijken samen te hangen. De moderator 'het aantal sessies dat ouders bijwonen' was uiteindelijk de enige die de interventie-effecten beïnvloedde. We vonden echter geen consistent patroon van deze moderator op alle uitkomstmaten: het aantal sessies dat ouders bijwonen bleek het interventie-effect op gerapporteerd negatief opvoedgedrag en gerapporteerd en geobserveerd positief opvoedgedrag wel te modereren, maar dit was niet het geval bij de effecten op kindniveau. Onze bevindingen zijn daarom in strijd met vorige studies die moderatie-effecten vonden van bijvoorbeeld de ernst van het probleemgedrag bij aanvang van de interventie en SES (Lundahl et al. 2006; Menting et al. 2013). Dit zou enerzijds kunnen betekenen dat het aantal sessies dat ouders bijwonen een belangrijke moderator is. Anderzijds roepen onze resultaten de vraag op hoe universeel de onderzochte moderatoren zijn, wat hun unieke invloed is op de effectiviteit van IY, en als gevolg daarvan wat de ware klinische relevantie van deze moderatoren is in een geïndiceerde preventieve setting (gericht op het voorkomen van escalatie van beginnend probleemgedrag).

\section{Beperkingen van het onderzoek}

Onze resultaten moeten geïnterpreteerd worden in het licht van een aantal beperkingen. Ten eerste was er een groot aantal ouders dat in de interventiegroep geloot werd, maar niet heeft deelgenomen aan de interventie. Om een realistisch beeld te krijgen van de effectiviteit van IY in een 'reallife'-situatie hebben we gebruikgemaakt van een 'intention-to-treat'-model, waarbij alle gezinnen (ongeacht deelname) die gerandomiseerd waren in de interventiegroep mee werden genomen in de analyses. Een nadeel is echter dat dit een conservatieve manier van analyseren is en het effect van de training mogelijk hoger is onder de groep ouders die daadwerkelijk deelnamen aan IY.

Ten tweede hadden we een follow-up die slechts 4 maanden na afronding van IY plaatsvond. Daarom kunnen we alleen speculeren over de verandering van opvoedgedrag en het gedrag van het kind over een langere periode. Daarnaast is er meer onderzoek nodig om de langdurige rol van (potentiële) sociaal-demografische en interventie-specifieke moderatoren verder te toetsen. Een andere uitdaging voor toekomstig onderzoek is het onderzoeken van de onderliggende mechanismen van de effecten van IY. Hoewel we in dit en een ander artikel (Weeland et al. 2018) beschrijven dat IY zowel een positieve verandering in het opvoedgedrag van de ouder (alsmede de geobserveerde emoties die hiermee gepaard gaan) als in het probleemgedrag van het kind teweegbrengt, vonden we geen bewijs dat de verandering in 
opvoedgedrag de verandering in het gedrag van het kind daadwerkelijk verklaard (zie voor een uitgebreide discussie Weeland et al. 2018). Mogelijk is IY ook werkzaam via andere factoren, zoals vermindering van opvoedstress, verandering van attributies van ouders en vergroting van hun zelfvertrouwen (Feldman en Werner 2002; Mouton en Roskam 2015; Sawrikar en Dadds 2018). Toekomstige studies naar verandermechanismen (mediatie) zouden zich hier ook op moeten richten.

Ten derde is IY een zeer sterk geprotocolleerde ouderinterventie, uitgevoerd door gecertificeerde trainers, wat er mogelijk voor zorgt dat de interventie-integriteit hoog is (Webster-Stratton et al. 2001). Echter, het gebruik van zelfgerapporteerde interventie-integriteit, zoals in deze studie, wordt bekritiseerd, omdat die niet objectief zou zijn (Perepletchikova en Kazdin 2005). De integriteit valt mogelijk lager uit als we bijvoorbeeld (ook) observaties tijdens de bijeenkomsten hadden gebruikt.

Ten vierde bestond de steekproef van onze studie slechts voor een klein deel uit alleenstaande ouders en lage-SES-gezinnen. Het kleine aantal deelnemers met deze kenmerken maakt het moeilijker om een moderatie-effect hiervan te vinden.

Tot slot was de betrouwbaarheid van de schalen die gebruikt worden voor het geobserveerde gedrag van het kind laag $(\alpha=0,49-0,67)$, wat wellicht heeft geleid tot minder betrouwbare schattingen van het effect van IY hierop. Echter, in het kader van transparantie hebben we besloten deze toch als uitkomstmaat te rapporteren (zie ook onze a-priori-hypothesen in Chhangur et al. 2012).

\section{Sterke punten en conclusie}

De huidige RCT naar de effectiviteit van IY kan worden beschouwd als een belangrijke stap voorwaarts in het onderzoek naar moderatie van interventie-effecten door gebruik te maken van een grote steekproef, observatiematen, geavanceerde statistische analyses, het controleren voor kans-kapitalisatie, de hoge IY-deelname en de kleine uitval van deelnemers (behoud van $93 \%$ van de gezinnen ten tijde van de follow-up). We hebben voortgebouwd op resultaten van eerdere metaanalyses die veronderstelden dat de ernst van het probleemgedrag bij aanvang van de interventie, het geslacht van het kind, de SES, de gezinssamenstelling en het aantal sessies dat ouders bijwonen, belangrijke moderatoren zijn die de effectiviteit van ouderinterventies beïnvloeden. Tot nu toe werden deze potentiële moderatoren echter voornamelijk apart onderzocht met een relatief kleine steekproefgrootte (gemiddeld $N=95$; Menting et al. 2013). Onze resultaten laten zien dat de moderatoren niet zo krachtig zijn in het voorspellen van de effectiviteit van ouderinterventies dan eerder verwacht, wanneer je in een analyse controleert voor de samenhang tussen bovengenoemde moderatoren. Wij raden toekomstig onderzoek aan strikt te zijn bij de uitvoering van RCT's, data-analyses en het rapporteren van de resultaten. Op basis van onze studie kunnen we concluderen dat IY in een geïndiceerde preventieve setting, effectief is voor een diverse groep gezinnen, met name als het gaat om het verhogen van positief opvoedgedrag en het verminderen van probleemgedrag. 
Financiering Deze studie is gefinancierd door de Nederlandse Organisatie voor Wetenschappelijk Onderzoek (NWO: 452-10-005).

\section{Literatuur}

Benjamini, Y., \& Hochberg, Y. (2005). Controlling the false discovery fate: a practical and powerful approach to multiple testing. Journal of the Royal Statistical Society, 57, 289-300. Retrieved from http://www.jstor.org/stable/2346101.

Chhangur, R.R., Weeland, J., Overbeek, G., Matthys, W., \& Orobio de Castro, B. (2012). ORCHIDS: an observational randomized controlled trial on childhood differential susceptibility. BMC Public Health, 12, 917-923. https://doi.org/10.1186/1471-2458-12-917.

Daley, D., Oord, S. van der, Ferrin, M., Danckaerts, M., Doepfner, M., Cortese, S., \& Sonuga-Barke, E.J.S. (2014). Behavioral interventions in attention-deficit/hyperactivity disorder: a meta-analysis of randomized controlled trials across multiple outcome domains. Journal of the American Academy of Child and Adolescent Psychiatry, 53(e5), 835-47, 847.e1-5. https://doi.org/10.1016/j.jaac. 2014.05.013.

Durlak, J.A., \& DuPre, E.P. (2008). Implementation matters: a review of research on the influence of implementation on program outcomes and the factors affecting implementation. American Journal of Community Psychology, 41, 327-350. https://doi.org/10.1007/s10464-008-9165-0.

Eyberg, S. M., \& Pincus, D. (1999). Eyberg Child Behavior Inventory and Sutter-Eyberg Student Behavior Inventory-Revised: professional manual. Odessa: Psychological Assessment Resources.

Faul, F., Erdfelder, E., Lang, A.-G., \& Buchner, A. (2007). G*Power 3: a flexible statistical power analysis program for the social, behavioral, and biomedical sciences. Behavior Research Methods, 39, 175-191. https://doi.org/10.3758/BF03193146.

Feldman, M.A., \& Werner, S.E. (2002). Collateral effects of behavioral parent training on families of children with developmental disabilities and behavior disorders. Behavioral Interventions, 17(2), 75-83. https://doi.org/10.1002/bin.111.

Fossum, S., Mørch, W.T., Handegård, B.H., Drugli, M.B., \& Larsson, B. (2009). Parent training for young Norwegian children with ODD and CD problems: predictors and mediators of treatment outcome. Scandinavian Journal of Psychology, 50, 173-181. https://doi.org/10.1111/j.1467-9450. 2008.00700.x.

Gardner, F., Hutchings, J., Bywater, T., \& Whitaker, C. (2010). Who benefits and how does it work? Moderators and mediators of outcome in an effectiveness trial of a parenting intervention. Journal of Clinical Child \& Adolescent Psychology, 39, 568-580. https://doi.org/10.1080/15374416.2010. 486315.

Griffin, K.W., Botvin, G.J., Scheier, L.M., Diaz, T., \& Miller, N.L. (2000). Parenting practices as predictors of substance use, delinquency, and aggression among urban minority youth: moderating effects of family structure and gender. Psychology of Addictive Behaviors, 14, 174-184. https:// doi.org/10.1037/0893-164X.14.2.174.

Hendriks, A. M., Giessen, D. van der, Stams, G. J. J. M., \& Overbeek, G. (2017). The association between parent-reported and observed parenting: a multi-level meta-analysis. Psychological Assessment, versnelde online publicatie. https://doi.org/10.1037/pas0000500.

Hu, L. T., \& Bentler, P. M. (1999). Cutoff criteria for fit indices in covariance structure analysis: conventional criteria versus new alternatives. Structural Equation Modeling, 11, 1-55. https://doi.org/10. 1080/10705519909540118.

Jokela, M., Ferrie, J., \& Kivimäki, M. (2009). Childhood problem behaviors and death by midlife: the British National Child Development Study. Journal of the American Academy of Child and Adolescent Psychiatry, 48, 19-24. https://doi.org/10.1097/CHI.0b013e31818b1c76.

Karreman, A., Tuijl, C. van, Aken, M.A. van, \& Dekovic, M. (2006). Parenting and self-regulation in preschoolers: a meta-analysis. Infant and Child Development, 15, 561-579. https://doi.org/10. 1002/icd.478. 
Kazdin, A.E. (1995). Child, parent and family dysfunction as predictors of outcome in cognitive-behavioral treatment of antisocial children. Behaviour Research and Therapy, 33, 271-281. https://doi. org/10.1016/0005-7967(94)00053-M.

Leijten, P., Raaijmakers, M. A. J., Orobio de Castro, B., \& Matthys, W. (2013). Does socioeconomic status matter? A meta-analysis on parent training effectiveness for disruptive child behavior. Journal of Clinical Child \& Adolescent Psychology, 42, 384-392. https://doi.org/10.1080/15374416.2013. 769169.

Leijten, P., Raaijmakers, M.A.J., Orobio de Castro, B., \& Matthys, W. (2016). Incredible Years Ouderprogramma voor gedragsproblemen bij kinderen uit laagopgeleide en migrantengezinnen. Systeemtherapie, 28, 233-241.

Leijten, P., Raaijmakers, M. A., Orobio de Castro, B., Ban, E. van den, \& Matthys, W. (2017). Effectiveness of The Incredible Years parenting program for families with socioeconomically disadvantaged and ethnic minority backgrounds. Journal of Clinical Child \& Adolescent Psychology, 46(1), 59-73. https://doi.org/10.1080/15374416.2015.1038823.

Lundahl, B., Risser, H. J., \& Lovejoy, M.C. (2006). A meta-analysis of parent training: moderators and follow-up effects. Clinical Psychology Review, 26, 86-104. https://doi.org/10.1016/j.cpr.2005.07. 004.

Matson, J.L., Rotatori, A.F., \& Helsel, W. J. (1983). Development of a rating scale to measure social skills in children: the Matson Evaluation of Social Skills with Youngsters (MESSY). Behaviour Research and Therapy, 21, 335-340. https://doi.org/10.1016/0005-7967(83)90001-3.

McCart, M.R., Priester, P.E., Davies, W.H., \& Azen, R. (2006). Differential effectiveness of behavioral parent-training and cognitive-behavioral therapy for antisocial youth: a meta-analysis. Journal of Abnormal Child Psychology, 34, 527-543. https://doi.org/10.1007/s10802-006-9031-1.

McMahon, R. J., Wells, K.C., \& Kotler, J.S. (2008). Conduct problems. In E. J. Mash \& R. A. Barkley (red.), Treatment of childhood disorders (3e druk. pag. 137-268). New York: Guilford.

Menting, A. T., Orobio de Castro, B., Wijngaards-de Meij, L. D., \& Matthys, W. (2014). A trial of parent training for mothers being released from incarceration and their children. Journal of Clinical Child \& Adolescent Psychology, 43(3), 381-396. https://doi.org/10.1080/15374416.2013.817310.

Menting, A. T., Orobio de Castro, B., \& Matthys, W. (2015). Effectiviteit van Betere Start, opvoedondersteuning voor (ex-) gedetineerde moeders. Kind \& Adolescent, 36(3), 127-145.

Menting, A. T. A., Orobio de Castro, B., \& Matthys, W. (2013). Effectiveness of The Incredible Years parent training to modify disruptive and prosocial child behavior: a meta-analytic review. Clinical Psychology Review, 33, 901-913. https://doi.org/10.1016/j.cpr.2013.07.006.

Moens, M. A., Weeland, J., Giessen, D. van der, Chhangur, R. R., \& Overbeek, G. (2018). In the eye of the beholder? Parent-observer discrepancies in parenting and child disruptive behavior assessments. Journal of Abnormal Child Psychology. https://doi.org/10.1007/s10802-017-0381-7.

Mouton, B., \& Roskam, I. (2015). Confident mothers, easier children: a quasi-experimental manipulation of mothers' self-efficacy. Journal of Child and Family Studies, 24(8), 2485-2495. https://doi.org/ 10.1007/s10826-014-0051-0.

Muthén, L. K., \& Muthén, B. O. (2010). Mplus user's guide (6e druk.). Los Angeles: Muthén \& Muthén.

Olson, S. L., Choe, D.E., \& Sameroff, A. J. (2017). Trajectories of child externalizing problems between ages 3 and 10 years: contributions of children's early effortful control, theory of mind, and parenting experiences. Development and Psychopathology, 29, 1333-1351. https://doi.org/10.1017/ S095457941700030X.

Perepletchikova, F., \& Kazdin, A.E. (2005). Treatment integrity and therapeutic change: issues and research recommendations. Clinical Psychology: Science and Practice, 12, 365-383.

Posthumus, J.A., Raaijmakers, M.A.J., Maassen, G.H., Engeland, H. van, \& Matthys, W. (2012). Sustained effects of Incredible Years as a preventive intervention in preschool children with conduct problems. Journal of Abnormal Child Psychology, 40, 487-500. https://doi.org/10.1007/s10802011-9580-9.

Reyno, S.M., \& McGrath, P. J. (2006). Predictors of parent training efficacy for child externalizing behavior problems: a meta-analytic review. Journal of Child Psychology and Psychiatry, 47, 99-111. https://doi.org/10.1111/j.1469-7610.2005.01544.x.

Robinson, E. A., \& Eyberg, S. M. (1981). The Dyadic Parent-Child Interaction Coding System: standardization and validation. Journal of Consulting and Clinical Psychology, 49, 245-250. https://doi. org/10.1037/0022-006X.49.2.245. 
Rothbaum, F., \& Weisz, J.R. (1994). Parental caregiving and child externalizing behavior in nonclinical samples: a meta-analysis. Psychological Bulletin, 116, 55-74.

Ruma, P. R., Burke, R. V., \& Thompson, R.W. (1996). Group parent training: is it effective for children of all ages? Behavior Therapy, 27, 159-169. https://doi.org/10.1016/S0005-7894(96)80012-8.

Sandler, I., Schoenfelder, E., Wolchik, S., \& MacKinnon, D. (2011). Long-term impact of prevention programs to promote effective parenting: lasting effects but uncertain processes. Annual Review Psychology, 62, 299-329. https://doi.org/10.1146/annurev.psych.121208.131619.

Sawrikar, V., \& Dadds, M. (2018). What role for parental attributions in parenting interventions for child conduct problems? Advances from research into practice. Clinical Child and Family Psychology Review, 21(1), 41-56. https://doi.org/10.1007/s10567-017-0243-4.

Scott, S. (2001). Deciding whether interventions for antisocial behaviour work: principles of outcome assessment, and practice in a multicentre trial. European Child and Adolescent Psychiatry, 10, 59-70.

Scott, S., \& O'Connor, T.G. (2012). An experimental test of differential susceptibility to parenting among emotionally-dysregulated children in a randomized controlled trial for oppositional behavior. Journal of Child Psychology and Psychiatry, 53, 1184-1193. https://doi.org/10.1111/j.14697610.2012.02586.x.

Scott, S., Knapp, M., Henderson, J., \& Maughan, B. (2001). Financial cost of social exclusion: follow up study of antisocial children into adulthood. BMJ, 323(7306), e191. https://doi.org/10.1136/bmj. 323.7306.191.

Sessa, F. M., Avenevoli, S., Steinberg, L., \& Morris, A.S. (2001). Correspondence among informants on parenting: preschool children, mothers, and observers. Journal of Family Psychology, 15, 53. https://doi.org/10.1037/0893-3200.15.1.53.

Sonuga-Barke, E. J. S., Brandeis, D., Cortese, S., Daley, D., Ferrin, M., Holtmann, M., Sergeant, J., et al. (2013). Nonpharmacological interventions for ADHD: systematic review and meta-analyses of randomized controlled trials of dietary and psychological treatments. American Journal of Psychiatry, 170, 275-289. https://doi.org/10.1176/appi.ajp.2012.12070991.

Stifter, C. A., Willoughby, M. T., \& Towe-Goodman, N. (2008). Agree or agree to disagree? Assessing the convergence between parents and observers on infant temperament. Infant and Child Development, 17, 407-426. https://doi.org/10.1002/icd.584.

Stumm, S. von, Deary, I. J., Kivimäki, M., Jokela, M., Clark, H., \& Batty, G.D. (2011). Childhood behavior problems and health at midlife: 35-year follow-up of a Scottish birth cohort. Journal of Child Psychology and Psychiatry, 52(9), 992-1001. https://doi.org/10.1111/j.1469-7610.2011. 02373.x.

Sullivan, G. M., \& Feinn, R. (2012). Using effect size - or why the p value is not enough. Journal of Graduate Medical Education, 4, 279-282. https://doi.org/10.4300/JGME-D-12-00156.1.

Webster-Stratton, C. (1989). Dyadic Parent-Child Interaction Coding System - Revised. Unpublished manuscript.

Webster-Stratton, C. (2001a). Parenting Practices Interview. Unpublished assessment instrument. http:// www.son.washington.edu/centers/parenting-clinic/forms.asp. Geraadpleegd op 17 september 2018.

Webster-Stratton, C. (2001b). The Incredible Years: parents and children videotape series: a parenting course (BASIC). Seattle: Incredible Years.

Webster-Stratton, C., Reid, J., \& Hammond, M. (2001). Social skills and problem-solving training for children with early-onset conduct problems: who benefits? Journal of Child Psychology and Psychiatry, 42, 943-952. https://doi.org/10.1111/1469-7610.00790.

Weeland, J., Chhangur, R.R., Jaffee, S.R., Giessen, D. van der, Matthys, W., Orobio de Castro, B., \& Overbeek, G. (2018). Does The Incredible Years reduce child externalizing problems through improved parenting? The role of child negative affectivity and serotonin transporter linked polymorphic region (5-HTTLPR) genotype. Development and Psychopathology, 30(1), 93-112. https:// doi.org/10.1017/S0954579417000499.

Weersing, V.R., \& Weisz, J.R. (2002). Mechanisms of action in youth psychotherapy. Journal of Child Psychology and Psychiatry, 43, 3-29. https://doi.org/10.1111/1469-7610.00002.

Weisz, J.R., \& Kazdin, A.E. (2010). The present and future of evidence-based psychotherapies for children and adolescents. In J. R. Weisz \& A.E. Kazdin (red.), Evidence-based psychotherapies for children and adolescents (Second Edition). New York: Guilford.

Wilson, D. B., \& Lipsey, M.W. (2001). The role of method in treatment effectiveness research: evidence from meta-analysis. Psychological Methods, 6, 413-429. 
Zahn-Waxler, C., Iannotti, R. J., Cummings, E. M., \& Denham, S. (1990). Antecedents of problem behaviors in children of depressed mothers. Development and Psychopathology, 2, 271-291. https:// doi.org/10.1017/S0954579400000778.

Dr. Joyce Weeland is universitair docent forensische orthopedagogiek aan de Faculteit der Maatschappij- en Gedragswetenschappen van de Universiteit van Amsterdam.

Dr. Rabia R. Chhangur is gedragswetenschapper en senior data-analist bij het Actiecentrum Veiligheid en Zorg van de Gemeente Amsterdam.

Dr. Daniëlle van der Giessen is universitair docent opvoedings- en ontwikkelingsproblemen aan de Faculteit der Maatschappij- en Gedragswetenschappen van de Universiteit van Amsterdam.

Prof. dr. Walter Matthys is emeritus hoogleraar educatie en pedagogiek - orthopedagogiek (psychosociale problemen) aan de Faculteit Sociale Wetenschappen van de Universiteit Utrecht.

Prof. dr. Bram Orobio de Castro is hoogleraar ontwikkelingspsychologie aan de Faculteit Sociale Wetenschappen van de Universiteit Utrecht.

Prof. dr. Geertjan Overbeek is hoogleraar pedagogiek aan de Faculteit der Maatschappij- en Gedragswetenschappen van de Universiteit van Amsterdam. 